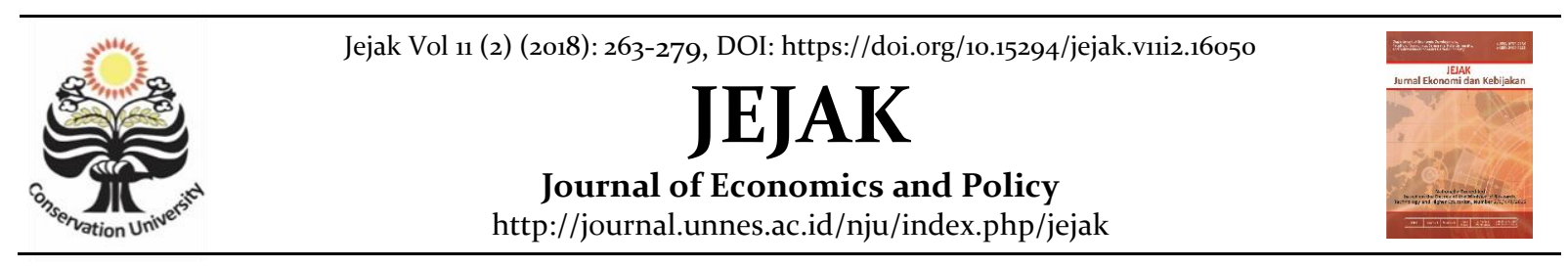

\title{
Utilization and Management Model of Pelagic Fish Resources
}

\author{
Herna Octivia Damayanti ${ }^{凶}$ \\ Regional Development Planning Agency of Pati Regency \\ Permalink/DOI: https://doi.org/10.15294/jejak.v11i2.16050 \\ Received: March 2018; Accepted: June 2018; Published: September 2018
}

\begin{abstract}
Pelagic fish was the main raw material for fish processing industry. Rate of fishing that not equivalent with the growth of fish resources, eventually will decrease the catch of fishermen. Aims of the research were (1) to estimate the bioeconomic of pelagic fish resources on MSY (Maximum Sustainable Yield), MEY (Maximum Economic Yield) and OA (open Access) conditions; (2) to estimate the optimum utilization rate, (3) arrange the management model of sustainability pelagic fish resources in Pati regency. This research was descriptive quantitative and conducted in March until September 2017. Reseacrh location in Bajomulyo village and Bendar village Juwana Subdistrict with 35 samples. Data analysis : (1) gear standardization, (2) bioeconomic static optimation model approach, (3) bioeconomic dinamic optimation model approach, (4) reconstruction of in-depth interview results. Result of the research are (1) bioeconomic static optimation model approach namely, biomass MEY $>$ MSY $>0 A$, catch MSY $>$ MEY $>0 A$, effort $\mathrm{OA}>\mathrm{MSY}>\mathrm{MEY}$, profit MEY>MSY>OA; (2) bioeconomic dinamic optimation model approach namely, biomass MEY $>\mathrm{MSY}>0 \mathrm{OSY}>0 \mathrm{~A}$, catch $\mathrm{MSY}>\mathrm{MEY}>\mathrm{OSY}>\mathrm{OA}$, effort $\mathrm{OA}>\mathrm{MSY}>\mathrm{OSY}>\mathrm{MEY}$, profit $\mathrm{MEY}>>\mathrm{OSY}>\mathrm{MSY}>\mathrm{OA}$; (3) pelagic fish management model are input controlling, output controlling and technical provisions.
\end{abstract}

Key words : bioeconomic, static-model, dinamic-model, pelagic-fish

How to Cite: Damayanti, H. (2018). Utilization and Management Model of Pelagic Fish Resources. JEJAK: Jurnal Ekonomi dan Kebijakan, 11(2), 263-279. doi:https://doi.org/10.15294/jejak.v11i2.16050 


\section{INTRODUCTION}

Pati regency is one of the areas in Central Java Province that supports the marine fisheries production in Central Java. In 2015, the production of Pati regency was ranked in second place compared to 2014 with $16.21 \%$ contribution. Rembang regency was the largest contributor of marine fisheries in Central Java with $20.48 \%$, third place was Batang regency with $8.61 \%$. The other areas that contribute to marine fisheries, among others Pemalang regency 8.44\% and Cilacap regency $4.42 \%$ (Central Statistics Agency of Central Java Province, 2015, 2016).

The amount of wet marine fish production in Pati regency is dominated by Decapterus russelli, Sardinella longiceps, Upenephelus sulphureus, Caesio erythrogaster, Priacanthus tayanus and Geres punctatus. The largest type of catch is Decapterus russelli. Decapterus russelli is one of the small pelagic fish species. The increase in catch percentage from 2014 to 2015 amounted to $422.70 \%$. In 2016 , catches of Decapterus russelli decreased by $48.20 \%$. Some things that may lead to reduced the production include seasonal influences, or may be due to the effect of fishing efforts or even fish stocks. Pelagic fish, especially small pelagic fish is the main raw material for the industry of boiled fish, curing, salting, fish meal. This was in accordance with the results of the research by Damayanti (2014) mentioned that the common types processed by way of boiled fish is a kind of pelagic fish such as Decapterus russelli, Selaroides leptolepis, Dussumieria acuta, Sardinella gibbosa, Sardinella longiceps and others. The same was stated by Sutanto (2015) mentioned that the types of fish used as raw materials of salted fish such as Decapterus russelli,
Sardinella longiceps and others. Thus, the presence of pelagic fish stock is very important for the sustainability of the fishery processing industry.

Utilization of pelagic fish for the processing industry causes fishermen try to maximize the catch. The way taken is to increase the capture effort in the hope of obtaining maximum results. However, if the rate of fishing not equivalent with the growth of fish resources, fish stocks will decrease and eventually lead to a decrease in the catch of fishermen. If this condition occurs, it's in accordance with the statement of Sparre and Vanema (1999) known by overfishing in the term of biology (biological overfishing)

Overfishing conditions will affect the ability of fish resources to regenerate due to excessive exploitation, that will cause fish stocks to decline and do not have the opportunity to breed. This is stated by Nikijuluw (2002) that the overfishing status of fish resources in a waters is basically related to the intensity or frequency of fishing effort and the ability of fish resources to regenerate. In addition to the effect on the decrease of fishermen catch, this will also directly affect the production of processing industries that use pelagic fish as the main raw material.

The problem of fish resources becomes one of the important problems in the development of capture fisheries in realizing the optimal and sustainable capture fisheries development. The availability of fish resources is influenced by the internal factors of fish, especially related to the ability of fish regeneration to environmental changes both due to natural factors and human activities. Empirical facts showed that the degradation of fish resources is largely due to human 
activities in exploiting fish resources that exceed the limits of the ability of fish to regenerate. Therefore, the demands of human needs in exploiting fish resources (economic interests) must be balanced with the demands of the availability of fish resources in the future (interests of fish resources and the environment) (Directorate General of Capture Fisheries Ministry of Marine Affairs and Fisheries of Indonesia Republic, 2015).

Pelagic fish catchment area of Pati regency fishermen are Java sea (Fisheries Management Area/FMAs Indonesia Republic 712), Makasar Straits (FMAs Indonesia Republic 713) and Arafuru Sea (FMAs Indonesia Republic 718). The capture status or utilization rate of pelagic fish resources in the fish catchment areas of Pati Regency (WPP-RI 712, 713 and 718) was generally in overfishing status. Data from the Fisheries Research Center of 2014 mentioned that for FMAs Indonesia Republic 712 Java Sea, the utilization rate of small pelagic fish resources in the Java Sea was on the red indicator, which means it was closed for the addition of new efforts. For large pelagic fish, the utilization rate of large pelagic fish resources has reached the yellow indicator, which means it has to be careful in the addition of efforts. FMAs Indonesia Republic 713 Makassar Strait, Bone Bay, Flores Sea and Bali Sea, the utilization rate of small pelagic fish resources was on green indicator. For large pelagic fish, the utilization rate of large pelagic fish resources was already at full stage (red indicator). FMAs Indonesia Republic 718 Aru Sea, Arafuru Sea and East Timor Sea, the utilization rate of small pelagic fish resources was already reached red indicator or has exceeded its sustainable potential. For large pelagic fish, the utilization rate of large pelagic fish resources was on the red indicator or has exceeded the potential of its sustainable potential (Marine Fisheries Research Center, 2014).

Therefore, it is necessary to study the pelagic fish management in Pati Regency so that it is expected to be able to continuously manage the pelagic fish resources in Pati Regency. One way that can be used is by doing bioeconomic analysis

Bioeconomic fishery comes from three words namely biology, economy, and fishery. Biology comes from the word "bio" which means life and "logos" which means science. Therefore, it is simply interpreted as a science that studies the life of biological beings, including fish resources. While the economy is defined as the study of human or community behavior in determining the choice to use scarce resources in an effort to improve the quality of life. This bioeconomic approach is needed in the management of fish resources because management has been based on biological approaches only when Schaefer introduced the concept of MSY. The MSY concept is aimed at the biological approach of obtaining maximum production and ignoring the fish harvesting costs, not considering the socio-economic aspects of the fish resources management and not taking into account the economic value of unharvested resources. The shortcomings of the biological approach gave birth to a new concept of bioeconomic approach. With the bioeconomic aspects of social and economic become important in management. In the biological approach the main objective is biological growth but in the bioeconomic approach the main objective is the economic aspect with the constraints of the biological aspect of fish resources (Fauzi and Anna, 2005). 
Previous studies have been conducted on the condition of small pelagic fish resource management with bioeconomic analysis such as : a research conducted by Mulyani et al (2004) on the management of anchovy resources with jabur gear through bioeconomic appoach in Tegal waters. The method used was the production surplus and static bioeconomic model Schaefer. The result of the research showed that (a) optimal capture effort 19,576.77 trip, (b) MSY of anchovy resources $676,588.06 \mathrm{~kg} /$ year and (c) economically anchovy fishing business with jabur gear was still profitable but biologically the anchovy resources was overfishing in Tegal waters.

Another research conducted by Ernaningsih (2013) on the bioeconomics of small pelagic fishes in Banten Bay used the production surplus method. The results of the research showed that (a) there are seven species of small pelagic fish found throughout the year in Banten Bay; (b) the potential of anchovy resources was large, but the utilization rate already exceeded the allowable catch of $81.79 \%$ and (c) species of Rastrelliger spp, biologically has a smaller potential than anchovy but economically more profitable at 4.8 billion rupiahs.

Therefore, in order to be able to carry out sustainable management, the research objectives are (1) to estimate the bioeconomic of pelagic fish resources in various management conditions, namely Maximum Sustainable Yield (MSY), Maximum Economic Yield (MEY), and Open Access (AO) ; (2) to estimate the optimal utilization rate of pelagic fish resources in Pati Regency, and (3) to arrange the sustainable pelagic fish resource management model in Pati regency.

\section{RESEARCH METHODS}

The research located in Bajomulyo Village and Bendar Village, Juwana Subdistrict, Pati Regency. The study time was 7 months, started from March to September 2017. The population in this study were small pelagic fishermen. That was because the captured fish majority in Pati Regency was small pelagic fish. Technique of sampling research done by multi stage sampling with stages as followed:

\section{Step I}

Specifies the type of fishing gear

The type of fishing gear of pelagic fish in Pati Regency was Purse Seine and gill net. Research population were 35 Purse Seines (gear that made the standard) (Bajomulyo fish landing base, 2017). The population was obtained based on certain criteria:

Table 1. Research Population Criteria

\begin{tabular}{|c|c|}
\hline Number & Criteria \\
\hline 1. & Small pelagic fish fishermen \\
\hline 2. & $\begin{array}{l}\text { Used purse seine gear (gear that } \\
\text { made the standard) }\end{array}$ \\
\hline 3. & Boat size $80-90 \mathrm{GT}$ \\
\hline 4. & $\begin{array}{l}\text { The location near with Bajomulyo } \\
\text { auction (Bendar village and } \\
\text { Bajomulyo village) }\end{array}$ \\
\hline
\end{tabular}

Source : Data analysis (2017)

\section{Gear Standardization}

In general, each type of fishing unit is able to capture various types of fish resources in a fishing area, but the capability of each fishing unit varies in yield. Standardization of capture efforts needs to be done by comparing catch per unit effort (CPUE) of each fishing unit (Pratiwi, 2009). 
Gear that used as a standard is a gear that has a high productivity (dominant) in capturing small pelagic fish resources that become the object of research, or has the highest average value of CPUE in a period of time and has Fishing Power Index worth to one. In this research, gear used as a standard $(\mathrm{FPI}=1)$ is small pelagic fish Purse Seine, because it has more units and more production than Gill net, so the value of productivity is higher. Calculation of gear standardization follows the following formula:

$\begin{array}{ll}\left.\text { 1) } C P U E_{s}=\frac{Y_{s}}{E_{s}} ; 3\right) F P I_{s}=\frac{C P U E_{s}}{C P U E_{s}} & \\ \left.\text { 2) } C P U E_{n}=\frac{Y_{n}}{E_{n}} ; 4\right) F P I_{n}=\frac{C P U E_{n}}{C P U E_{s}} & \end{array}$

Figure 1. Gear Standardization Formula Source : Pratiwi, 2009

Description :

CPUE $_{n}$ : CPUE of gear to be standardized year-i

$\mathrm{CPUE}_{\mathrm{s}}$ : CPUE of standard gear year-i

$\mathrm{Y}_{\mathrm{s}} \quad$ : The catch from standard gear year-i

$\mathrm{Y}_{\mathrm{n}} \quad$ : The catch from gear to be standardized year-i

$\mathrm{E}_{\mathrm{s}} \quad$ : effort from standard gear year-i

$E_{n} \quad$ : effort from gear to be standardized year-i

\section{Step II}

Determining the research sample that is all the population used as research samples. The distribution of research samples are presented in Table 2.

According to Wijayanto (2008), static bio-economic analysis based on the GordonSchaefer model uses the logistical growth function developed by Gordon. The growth function model is combined with economic principles by including price factor per unit of catch and cost per unit effort on the function equation.

Table 2. The Distribution of Research

Samples

\begin{tabular}{clc}
\hline Number & \multicolumn{1}{c}{ Location } & Samples \\
\hline $\mathbf{1}$ & Bajomulyo village & $\mathbf{2 0}$ \\
$\mathbf{2}$ & Bendar village & $\mathbf{1 5}$ \\
\hline & Total & 35 \\
\hline
\end{tabular}

Source: Data analysis (2017)

Resources management using bioeconomic analysis was calculated on maximum economic yield (MEY), maximum sustainable yield (MSY), open access (OA), and optimum sustainable yield (OSY). The bioeconomic analysis of the static optimization model approach with the Gordon-Schaefer model uses the following formula in Table 3.

Bioeconomic analysis of dynamic optimization model approach using time value of money approach or the price of time proposed by Seijo et al in Pratiwi (2009). Bioeconomic analysis is done by using discount rate $(\delta)$. The discount rate calculation for the extraction of fishery resources refers to the method proposed by Clark in Pratiwi (2009). The discount rate calculation is obtained from the equation:

$$
\begin{aligned}
& \delta_{\text {riil }}=\ln \left(1+i_{\text {ril }}\right) \\
& i_{\text {riil }}=i_{\text {nom }}-\inf
\end{aligned}
$$

Description : $\delta_{\text {riil }}=$ real discount rate

$$
\begin{aligned}
& i_{\text {riil }}=\text { real interest rate } \\
& i_{\text {nom }}=\text { nominal interest rate } \\
& \text { inf }=\text { inflation rate }
\end{aligned}
$$

In this research used the prevailing bank interest rate in the research area (Pati Regency) and when the research proposal was set (January 2017) at 10.50\% (Indonesian Bank, 2017a) with an inflation rate of 3.49\% (Indonesian Bank, 2017b). 
Table 3. Bioeconomic Analysis Calculation

\begin{tabular}{lccc}
\hline \multirow{2}{*}{ Variables } & \multicolumn{3}{c}{ Conditions } \\
\cline { 2 - 4 } Biomassa (x) & $\frac{K}{2}\left(1+\frac{c}{p q K}\right)$ & $\frac{K}{2}$ & MSY \\
Catch (h) & $\frac{r}{2 q}\left(1+\frac{c}{p q K}\right)\left(1-\frac{c}{p q K}\right)$ & $\frac{r K}{4}$ & $\frac{r c}{p q}\left(1-\frac{c}{p q K}\right)$ \\
Effort (E) & $p q K E\left(1-\frac{c}{p q K}\right)-c E$ & $p\left(\frac{r K}{4}\right)-c\left(\frac{r}{2 q}\right)$ & $\left(p-\frac{c}{p x}\right) F(x)$ \\
Rente Ekonomi $(\pi)$ & $\left.1-\frac{c}{p q K}\right)$ \\
\hline
\end{tabular}

Output of optimum dynamic/optimum sustainable yield (OSY) included optimum (xopt), optimum catch (hopt) and optimum effort (Eopt) with formula (Fauzi, 2010):

$$
x_{\text {opt }}=\frac{K}{4}\left\{\frac{c}{p q K}+1-\frac{\delta}{r}+\sqrt{\left(\frac{c}{p q K}+1-\frac{\delta}{r}\right)^{2}+\frac{8 c \delta}{p q K r}}\right\}
$$

Furthermore, to estimate the catch rate and optimum level of effort on the dynamic approach, ie catch and effort on optimum conditions or optimal sustainable yield (OSY) was calculated by the equation:

$$
\begin{aligned}
& h_{o p t}=r x_{o p t}\left(1-\frac{x_{o p t}}{K}\right) \\
& E_{o p t}=\frac{h_{o p t}}{q x_{o p t}}
\end{aligned}
$$

The pelagic fish resource management model were based on research results and reconstruction results. It was done by in- depth interview with the parties concerned. The phases of reconstruction strategy were as followed in-depth interview with keypersons, model reconstruction.

In-depth interview with keypersons from the Marine and Fishery Agency of Pati Regency, All Indonesian Fishermen Group of Pati regency, Community Leader and Purse Seine boat owner. The results of in-depth interview with Keypersons determine what aspects are related to the management of pelagic fish resources. In addition, it was also possible to know the priorities needed for the management of pelagic fish resources.

After in-depth interview, the next step was to synthesize (reconstruct) the management model. In addition based on the results of in-depth interview, also refers to literature study. 


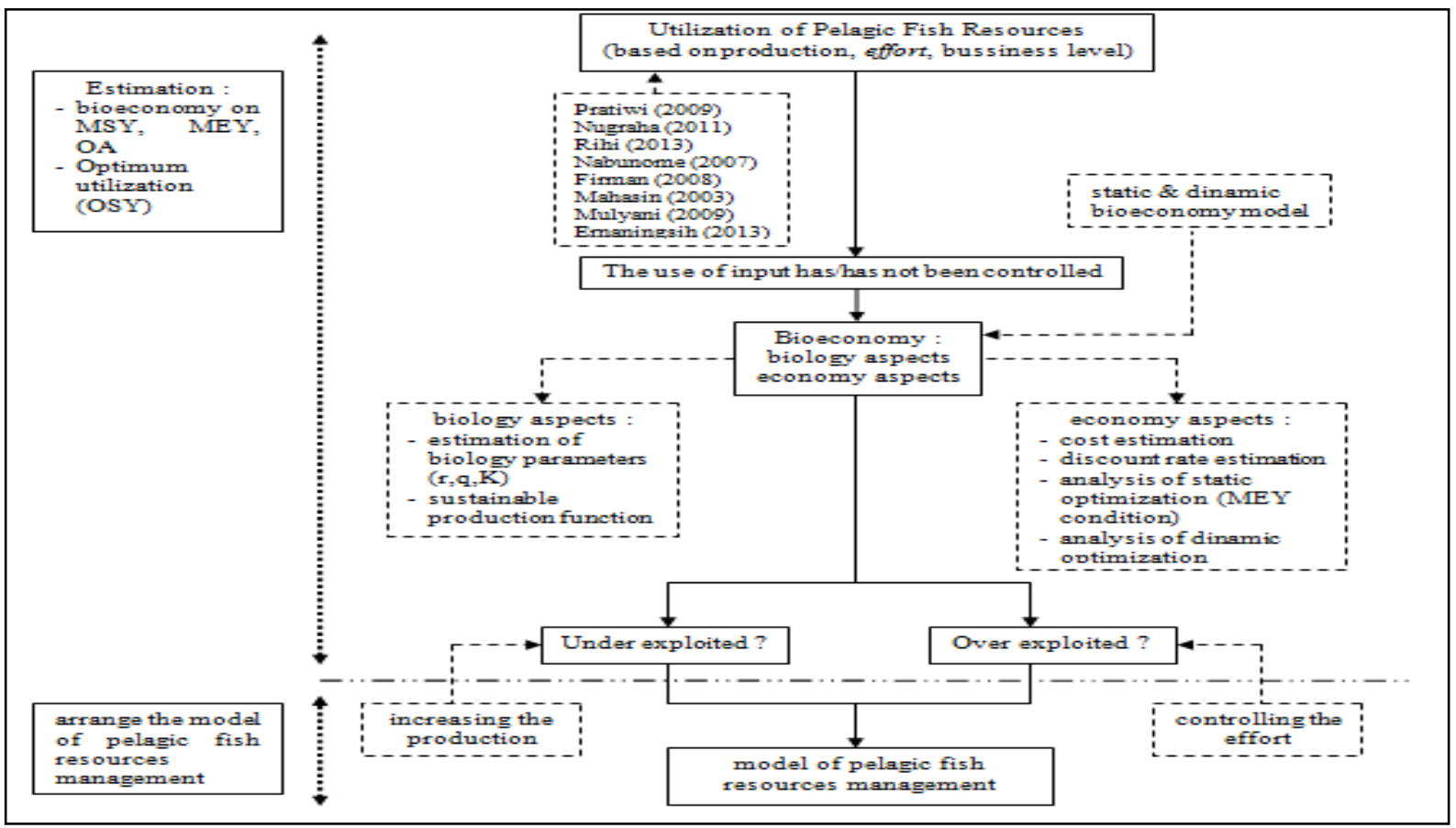

Figure 2. Research Design

Source : Data Analysis, 2017

\section{RESULTS AND DISCUSSION}

\section{Gear Standardization of Pelagic Fish in} Pati Regency

Gera standardization is done because each gear has different capture capabilities, both in species and number of fish that was caught. The gear used to catch pelagic fish in Pati Regency is purse seine and gill net.
Thus, the gear standardization is done on Purse Seine and Gillnet.

In this research, the gear used as a standard is Purse seine. Measurement of the effort as input is based on the number of trips from boat using Purse Seine and Gillnet. The result of gear standardization of pelagic fish in Pati Regency is presented in Table 4.

Table 4. Effort Standardization of Pelagic Fish Gear in Pati Regency

\begin{tabular}{|c|c|c|c|c|c|c|}
\hline \multirow{2}{*}{ Year } & \multicolumn{3}{|c|}{ Effort } & \multicolumn{2}{|c|}{ Fishing Power Index (FPI) } & \multirow{2}{*}{$\begin{array}{c}\text { Effort } \\
\text { standard }\end{array}$} \\
\hline & E Purse seine & E Gillnet & E total & FPI Purse seine & FPI Gillnet & \\
\hline 2007 & 93.00 & 0.44 & 93.44 & 1 & 0.0009 & 93.44 \\
\hline 2008 & 94.00 & 0.65 & 94.65 & 1 & 0.0013 & 94.65 \\
\hline 2009 & 126.00 & 0.44 & 126.44 & 1 & 0.0008 & 126.44 \\
\hline 2010 & 125.00 & 0.33 & $125 \cdot 33$ & 1 & 0.0006 & $125 \cdot 33$ \\
\hline 2011 & 132.00 & 0.42 & 132.42 & 1 & 0.0008 & 132.42 \\
\hline 2012 & 132.00 & 0.31 & 132.31 & 1 & 0.0006 & 132.31 \\
\hline 2013 & 132.00 & 0.60 & 132.60 & 1 & 0.0011 & 132.60 \\
\hline 2014 & 232.00 & 2.79 & 234.79 & 1 & 0.0051 & 234.79 \\
\hline 2015 & 238.00 & 1.61 & 239.61 & 1 & 0.0029 & 239.61 \\
\hline 2016 & 287.00 & 1.20 & 288.20 & 1 & 0.0014 & 288.20 \\
\hline
\end{tabular}

Source : Data Analysis (2017) 
Table 4 shows that effort standard for pelagic fish fishing in 2007 is 93.44 units; in 2008 is 94.65 units; in 2009 is 126.44 units; in 2010 is 125.33 units; in 2011 is 132.42 units; in 2012 is 132.31 units; in 2013 is 132.60 units; in 2014 is 234.79 units; in 2015 is 239.61 units and in 2016 is 288.20 units.

\section{Analysis of Catch Per Unit Effort (CPUE)}

Catch Per Unit Effort (CPUE) describes the productivity level of the effort. Nabunome (2007) states, the connection between CPUE and effort, the greater the effort, CPUE will decrease, so the production decreases. This means CPUE is inversely proportional to the effort where each additional of effort will make CPUE lower. This is due to the increased of competition between gear that operates where the resource capacity is limited and tends to decrease as effort continues to increase. Nurhayati (2013) stated that the decrease of production can occur because the operation area is very limited, so if catching intensity is high, it will cause the pressure on the fish resources become very big, which in the end will decrease the catch.

CPUE of pelagic fish gear in Pati Regency is the value of CPUE from Purse Seine and Gillnet. The average productivity of Purse Seine from 2007-2016 was 157.61 and the average productivity of Gillnet from 20072016 was 0.17. Thus, Purse Seine is more productive to catch pelagic fish than Gillnet, so the Purse Seine is used as a standard gear. CPUE of Purse Seine and Gillnet are presented in Table 5 .

The correlation between CPUE and Effort of pelagic fish in Pati Regency was analyzed with regression analysis as shown in Figure 3.
Table 5. CPUE of Purse seine and Gillnet in Pati Regency

\begin{tabular}{|c|c|c|c|c|}
\hline \multirow[b]{2}{*}{ Year } & \multicolumn{2}{|c|}{ Production } & \multicolumn{2}{|c|}{ CPUE } \\
\hline & $\begin{array}{l}\text { Purse } \\
\text { seine }\end{array}$ & Gillnet & $\begin{array}{c}\text { CPUE Purse } \\
\text { seine }\end{array}$ & $\begin{array}{c}\text { CPUE } \\
\text { Gillnet }\end{array}$ \\
\hline 2007 & $20,939 \cdot 90$ & 99.00 & 225.16 & 0.20 \\
\hline 2008 & $22,286.50$ & 154.85 & 237.09 & 0.31 \\
\hline 2009 & $26,223.63$ & 92.57 & 208.12 & 0.17 \\
\hline 2010 & $21,844.24$ & 57.61 & 174.75 & 0.11 \\
\hline 2011 & $27,544 \cdot 79$ & 87.46 & 208.67 & 0.18 \\
\hline 2012 & $30,811.24$ & 71.76 & 233.42 & 0.15 \\
\hline 2013 & $15,583.64$ & 71.22 & 118.06 & 0.13 \\
\hline 2014 & $6,085.27$ & 73.27 & 26.23 & 0.13 \\
\hline 2015 & $17,684.64$ & 119.42 & $74 \cdot 31$ & 0.21 \\
\hline 2016 & $20,179.99$ & 84.35 & 70.31 & 0.10 \\
\hline \multicolumn{3}{|c|}{ Total } & $1,576.13$ & 1.69 \\
\hline \multicolumn{3}{|c|}{ Average } & 157.61 & 0.17 \\
\hline
\end{tabular}

Source : Data Analysis (2017)

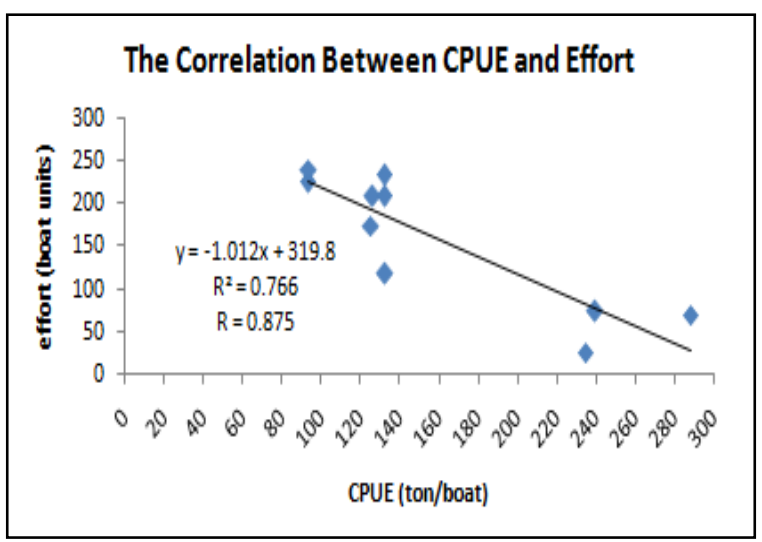

Figure 3. The Correlation Between CPUE and Effort of Pelagic Fish in Pati Regency Source : Data Analysis, 2017

Figure 3 shows a correlation that is directly proportional, if any increase will decrease the CPUE. The correlation of CPUE and effort with surplus production analysis is illustrated in the equation::

$$
Y=-1,012 X+319,8
$$

The equation shows that the intersep value ( $\alpha) 319.8$ and the slope $(\beta)$ value -1.012. The constants $(\alpha) 319.8$ means if there is no effort, the potentional valuable in nature 319.8 ton/trip. The regression coefficient $(\beta)$ 1.012 shows negatif correlation between 
production and effort, that any deduction (due to negative sign) 1 effort (unit boat) will cause CPUE to increase by 1.012 ton/boat. However, if effort increases by 1 unit of boat, then CPUE is also predicted to decrease by 1.012 ton/boat. Thus, the sign (-) denotes the direction of the inverse correlation, where the increase of the variable $\mathrm{X}$ will result in a decrease in the $\mathrm{Y}$ variable and otherwise.

The determination coefficient $\left(\mathrm{R}^{2}\right) 0.766$. This is shows that $76.6 \%$ CPUE value is influence by the effort, meanwhile $23.4 \%$ are influences by other factor such as season, weather and other biological factor.

The correlation coefficient/ $R$, the correlation between CPUE and effort 0.875 . This is shows that CPUE and efforthave high and tight correlation value, because the location of the correlation coefficient about o,7 $<$ KK $\leq$ 0,9 (Hasan, 2005).

Based on CPUE value and total catch, this is indicated that the capture of pelagic fish in Pati regency already in overfishing condition. Nabunome (2007), stated that one of overfishing characteristic is the cepture graph in unit of time fluctuated or erratically, overfishing condition can be detected by the decreasing of CPUE and decrease in total landed catches (Figure 4 and figure 5 ).

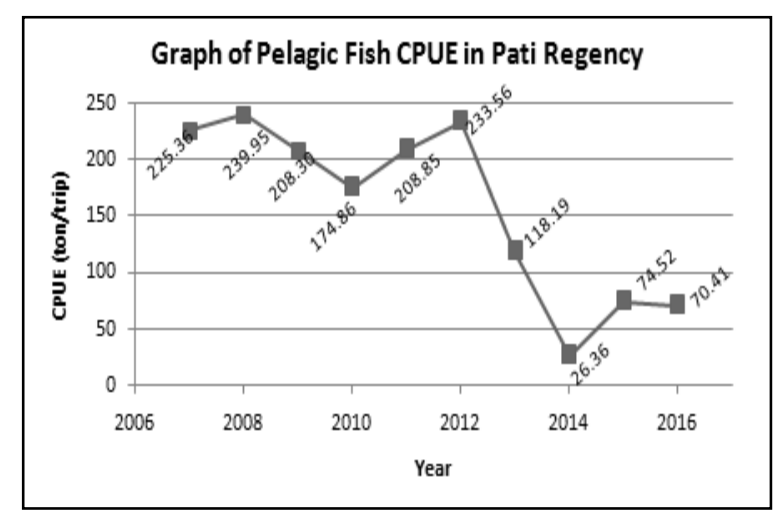

Figure 4. Graph of Pelagic Fish CPUE in Pati Regency

Source : Data analysis, 2017

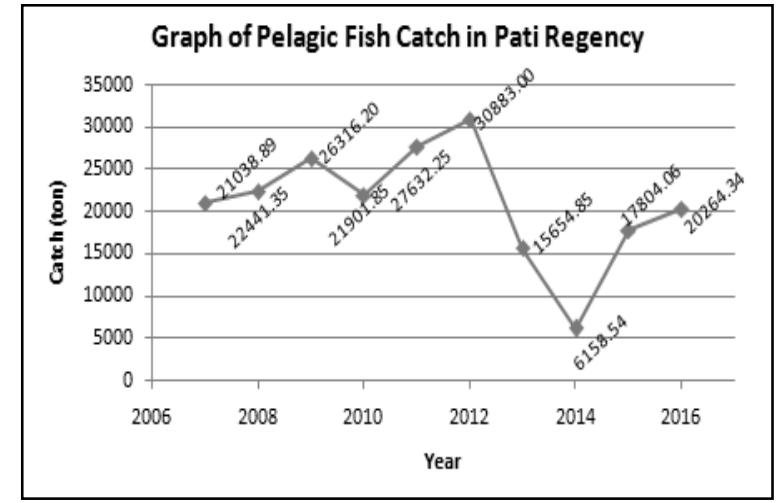

Figure 5. Graph of Pelagic Fish Catch in Pati Regency

Source : Data analysis, 2017

The correlation between catch and effort of pelagic fish in Pati regency in 2007 until 2016 can be seen in Figure 6.

The Maximum Sustainable Yield (MSY) of pelagic in Pati regency is the highest stock of pelagic fish that can be caught continuously for utilization in Pati Regency from an existing potency without affecting the preservation of existing pelagic fish stock. Based on the data analysis obtained the MSY of pelagic fish resources in Pati Regency is $25,264.83$ tons per year. $\mathrm{E}_{\mathrm{MSY}}$ is an effort that can be done by a fishing unit (boat) to obtain optimal catch without destroying the sustainability of pelagic fish resources. The EMSY of 158.004 or rounded to 158 units of boat. Department of Agriculture in Nurhayati (2013) stated that the utilization of pelagic fish resources potency based on prudential principle then Total Allowable Catch/TAC is $80 \%$ from MSY. Thus, the comparison between the pelagic fish production in Pati Regency with sustainable production is presented in Table 6 . 


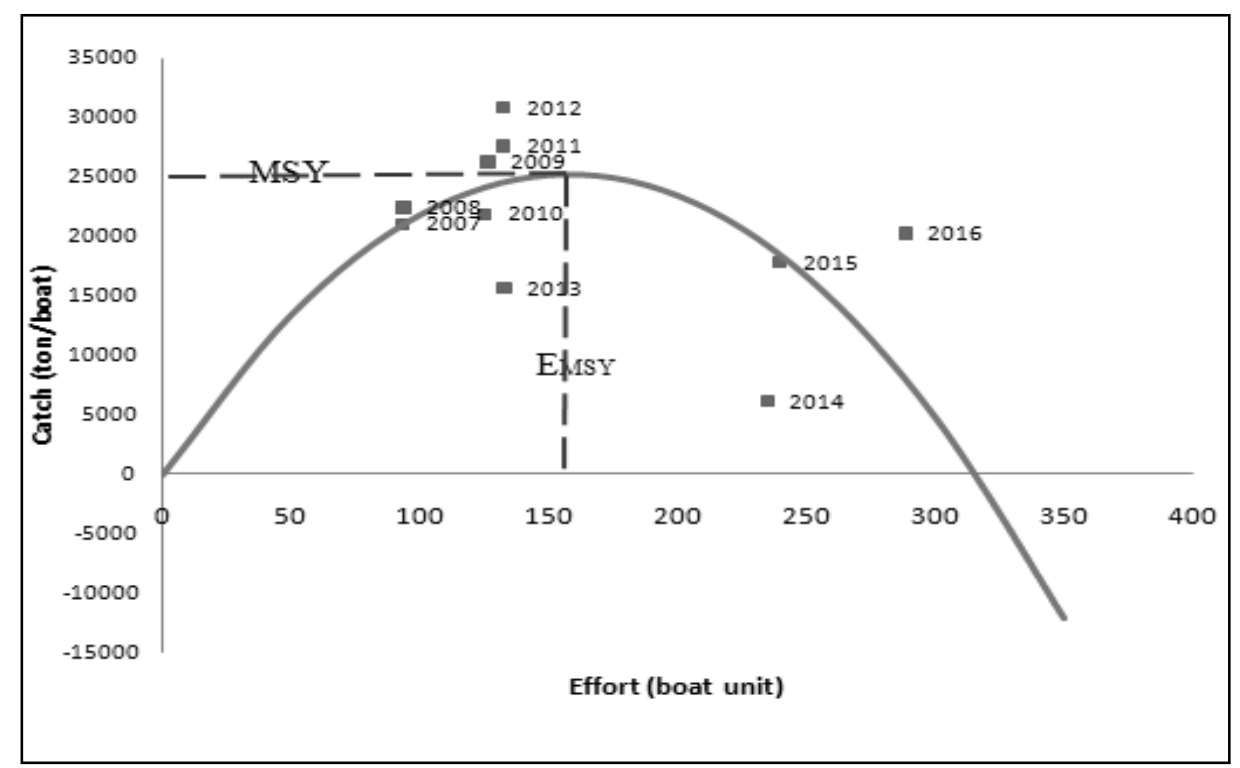

Figure 6. Graph of Correlation Between Catch and Effort in Pati Regency

Source : Data analysis, 2017

Table 6. The Utilization Rate of Pelagic Fish in Pati Regency Year 2007-2016

\begin{tabular}{cccccc}
\hline Year & Observed CPUE & Standard Effort & Production & TAC & Utilization (\%) \\
\hline 2007 & 225.36 & 93 & $21,038.89$ & $20,211.86$ & 104.09 \\
2008 & 239.95 & 94 & $22,441.35$ & $20,211.86$ & 111.03 \\
2009 & 208.30 & 126 & $26,316.20$ & $20,211.86$ & 130.20 \\
2010 & 174.86 & 125 & $21,901.85$ & $20,211.86$ & 108.36 \\
2011 & 208.85 & 132 & $27,632.25$ & $20,211.86$ & 136.71 \\
2012 & 233.56 & 132 & $30,883.00$ & $20,211.86$ & 152.80 \\
2013 & 118.19 & 133 & $15,654.85$ & $20,211.86$ & 77.45 \\
2014 & 26.36 & 235 & $6,158.54$ & $20,211.86$ & 30.47 \\
2015 & 74.52 & 240 & $17,804.06$ & $20,211.86$ & 88.09 \\
2016 & 70.41 & 288 & $20,264.34$ & $20,211.86$ & 104.36 \\
\hline \multicolumn{7}{c}{} \\
\hline
\end{tabular}

Source : Data analysis, 2017

Based on Table 6 it is known that TAC of pelagic fish in Pati regency amounted to 20,211.86 tons. The average utilization rate of pelagic fish resources in Pati Regency within 10 years $(2007-2016)$ is $104.36 \%$. In other words, the level of exploitation of pelagic fish resources in Pati Regency has exceeded $100 \%$. In general, it can be said that fluctuating catch and tends to decline in the period of 10 years (2007-2016) shows indication of overexploited of pelagic fish resources in Pati Regency.
The catch decreased although the effort was raised, allegedly because the effort has exceeded the maximum limit of fish's ability to recover. More capture events can often be detected by a combination of a number of stock indicators such as: (i) decrease in CPUE, (ii) decrease in total landing catch, (iii) decrease in average fish weight; and ecosystem indicators, ie (iv) changes in age structure/size structure or (v) changes in species composition in the population (Cahyani et al, 2013). 
Susilowati in Damayanti et al (2017) stated that if the utilization of resources was overexploited, then production rate will be in the range from in the end of phase II and phase III (mature production). Phase II in production theory means production that can achieve maximum amount of physical production (MSY), while phase III means production that does not profitor loss (break even point or open acsess).

\section{The Cost of Pelagic Fish Captured in Pati} Regency

The research cost of pelagic fish in Pati regency with purse seine was presented in Table 7.

Table 7. The Cost of Pelagic Fish Captured in Pati Regency

\begin{tabular}{lr}
\hline \multicolumn{1}{c}{ Description } & \multicolumn{1}{c}{ IDR } \\
\hline Total Cost & $\mathbf{5 2 5 , 9 5 0 , 9 5 6}$ \\
Fix Cost & $\mathbf{1 3 7 , 8 2 1 , 7 7 9}$ \\
Depreciation & $64,251,134$ \\
- Boat & $\mathbf{2 1 , 4 6 3 , 8 8 8}$ \\
- Engine & $4,803,620$ \\
- Gear & $12,173,777$ \\
- Freezer & $12,953,425$ \\
- Light & $12,856,424$ \\
Maintenance Cost & $43,919,048$ \\
Administration Cost & $16,795,172$ \\
Operational Cost & $388,129,177$ \\
Diesel Fuel & $169,606,857$ \\
Oil & $2,914,571$ \\
Consumption & $204,000,000$ \\
Book of The Crew List & 418,000 \\
Radio Permit & 148,571 \\
Sailing Permit & 148,571 \\
Fuel Refill Permit & 27,429 \\
Auction Retribution & $10,865,177$ \\
\hline
\end{tabular}

Source : Data analysis, 2017

According to Theresia et al (2013), the total cost is the overall cost of a business unit. Total cost are derived from the sum of fixed costs and non-fixed costs.Fixed costs are derived from the sum of depreciation costs, maintenance costs, and permit costs. While the non-fixed cost are obtained from operational costs and retribution cost. Based on the result of data processing conducted during the research, the average price of pelagic fish in Pati Regency is IDR 25,00o per $\mathrm{kg}$. The cost of pelagic fishing in Pati Regency with purse seine per year is IDR 525,950,956.

\section{Analysis of Pelagic Fish Resources of Bioeconomi Sumberdaya Pati Regency with Gordon-Schaefer Static Optimization Model}

The calculation result of static optimization analysis from each conditions, namely MSY, MEY and OA was presented in Table 9.

Table 9. The Result of Static Optimization Model of Pelagic Fish Resources

\begin{tabular}{lccc}
\hline Parameters & MSY & MEY & OA \\
\hline Biomass (x) & 158.004 & 168.398 & 20.789 \\
Catch (h) & $\mathbf{2 5 , 2 6 4 . 8 3 2}$ & $\mathbf{2 5 , 1 7 6 . 4 9 9}$ & $6,216.022$ \\
Effort (E) & 158.004 & 147.733 & 295.466 \\
Profit ( $\boldsymbol{\pi})$ & $546,512,048$ & $1,026,645,483$ & 0.000 \\
\hline \multicolumn{4}{l}{ Source : Data analysis, 2017 }
\end{tabular}

a) Maximum Sustainable Yield (MSY)

Biomass on MSY condition 158.004 tons; Catch 25,264.832 tons and effort 158.004 boat unit. Profit on MSY condition IDR $546,512,048$ or IDR $3,458,850$ per boat unit.

b) Maximum Economic Yield (MEY)

Biomass on MEY condition 168.398 tons; catch 25,176.499 tons and effort 147.733 boat unit. Profit on MEY condition IDR $1,026,645,483$ or IDR $6,949,335$ per boat unit. Correlation between profit per boat with effort was presented in Figure 7. 


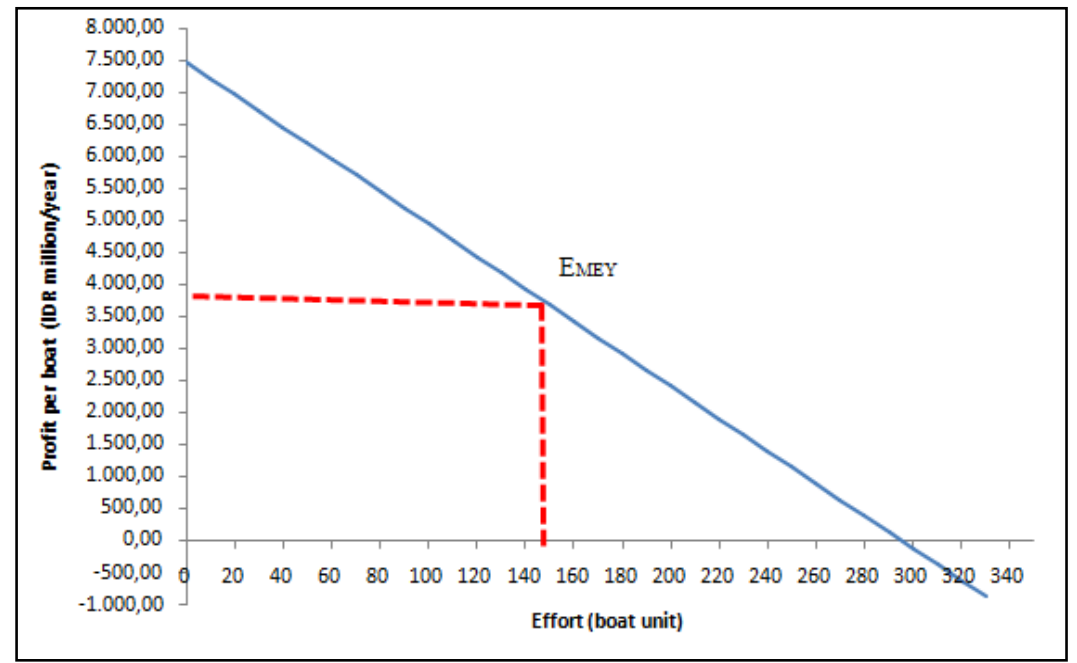

Figure 7. Correlation between profit per boat with effort of Pelagic Fish in Pati Regency

Source : Data analysis, 2017

Pratiwi (2009) mentioned that resource utilization that is limited to Maximum Economic Yield or a sole owner condition is a static condition that plays an important role in determining the balance of fishery resource utilization sustainably both biological and economic aspects. The gain is higher than in MSY and OA conditions. In the MEY condition, the level of fishing effort is efficient, resulting in better production, followed by maximum profit gain (see Table 9). In MEY condition, controlled resource utilization can be seen from the amount of effort needed that is smaller than in MSY and OA condition.

\section{c) Open Access (OA)}

The biomass in OA condition is 20.789 tons. The catch in OA condition is 6,216.022 tons with the effort of 295.466 boat units. The benefits gained on OA condition is IDR o. In OA conditions the gain is equal to zero ( $\mathrm{TR}=\mathrm{TC})$, this causes the fishermen to tend to increase the number of gear and increase the effort to obtain more results (Pratiwi,
2009). The number of effort in OA condition is 295.466 boat units, indicating twice the number of effort compared to MSY and MEY conditions.

The Correlation Between TR, TC, Profit and Effort of Pelagic Fish in Pati Regency with purse seine was presented in Figure 8.

\section{Estimation of Biological Parameters and Estimation of Discount Rate}

Estimation result of biological parameters namely $\mathrm{r}$ (growth rate), $\mathrm{K}$ (environmental carrying capacity), and q (catchability coefficient) of Fox Algorithm estimation model is presented in Table 9.

Table 9. Hasil Estimasi parameter biologi Sumberdaya Ikan Pelagis

\begin{tabular}{lr}
\hline \multicolumn{1}{c}{ Biological Parameters } & \multicolumn{1}{c}{ Value } \\
\hline Growth rate (r) (tons/year) & 316.008 \\
Enviromental carrying capacity & 1.012 \\
(K) (tons/year) & \\
Catchability coefficient (q) & 319.800 \\
(tons/boat unit) & \\
\hline Source : Data analysis, 2017
\end{tabular}




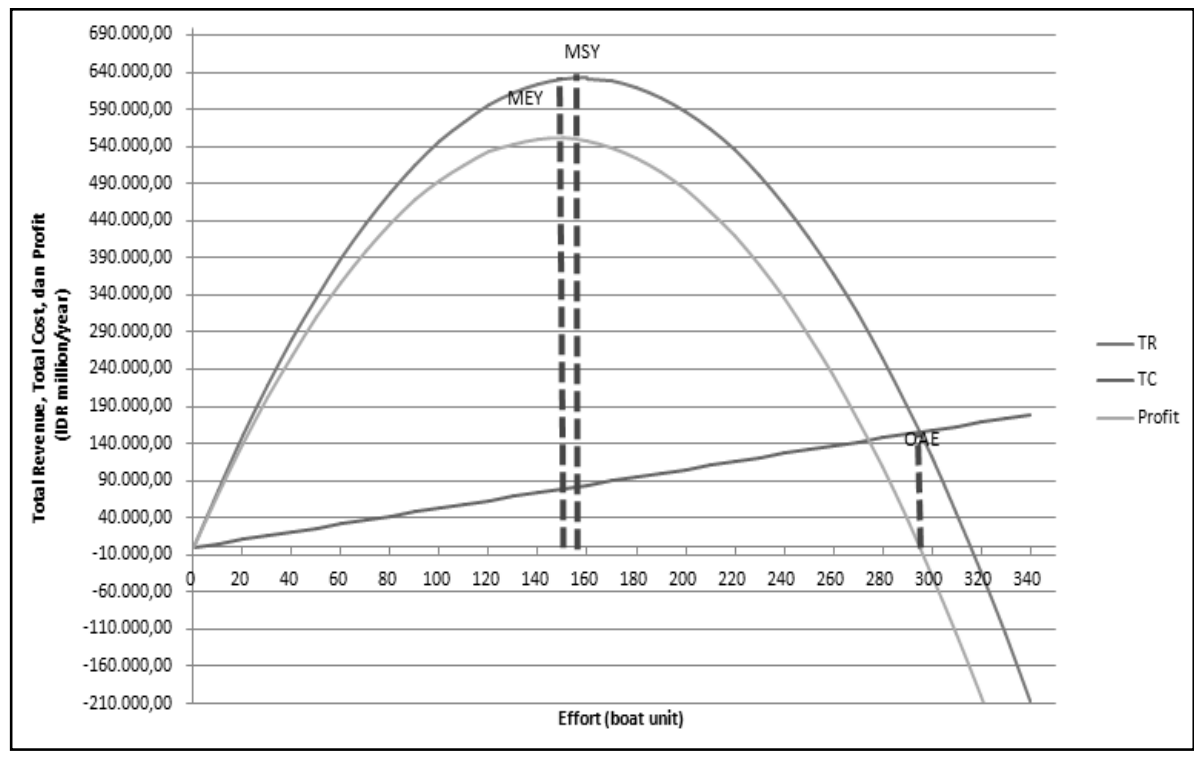

Figure 8. Correlation Between TR, TC, Profit and Effort of Pelagic Fish in Pati Regency Source : Data analysis, 2017

The natural growth rate of pelagic fish resources is 316.008 which means that pelagic fish resources will grow naturally without disturbance from natural phenomena or human activities with coefficient of 316.008 tons/year. Capture capability coefficient of 319.800 explained that each increase of fishing effort unit will affect 319.800 tons/boat unit to the catch of pelagic fish. Environmental carrying capacity of 1.012 indicates that the environment supports the production/catch of pelagic fish resources of 1.012 tons/year from the biological aspects that are food abundance, population growth and size of pelagic fish.

The discount rate and time parameters are the dynamic characteristics of the model.
In the dynamic approach, the use of discount rate is to obtain the optimal level of production, effort, economic rent and fish stock from the utilization of fish resources (Pratiwi, 2009). The calculation of discount rate in this research using the interest rate of $10.50 \%$ and the inflation rate of $3.49 \%$. The result of the discount rate $(\delta)$ is 2.081 .

Bioeconomy Analysis of Pelagis Fish Resources in Pati Regency with Dynamic Optimization Model

The results of biological and economic estimates are used to analyze the dynamics of pelagic fish resources. The results of optimal estimation/OSY (Optimum Sustainable Yield) are presented in Table 10.

Table 1o. Dynamic Optimization Results of Pelagic Fish Resources Utilization

\begin{tabular}{lcccc}
\hline \multicolumn{1}{c}{ Calculation } & $\begin{array}{c}\text { Biomass }(\mathbf{x}) \\
(\text { ton })\end{array}$ & $\begin{array}{c}\text { Catch }(\mathbf{h}) \\
(\text { ton })\end{array}$ & $\begin{array}{c}\text { Effort(E) } \\
(\text { unit })\end{array}$ & $\begin{array}{c}\text { Rente }(\boldsymbol{\pi}) \\
\text { (IDR Million) }\end{array}$ \\
\hline Dymanic & 167.498 & $25,173.617$ & 148.510 & $1,101,262.976$ \\
\hline Source : Data analysis, 2017 & & &
\end{tabular}


The biomass at optimum condition is 167.498 tons. The catch in optimum condition is $25,173.617$ tons with effort at optimal condition that is 148.510 units. The gain/rent obtained at the optimal condition is IDR 1,101,262,976. Thus, the gains obtained in optimal conditions are greater than in MSY, MEY and OA conditions.

Bioeconomic with dynamic model is an optimization analysis using discount rate, whereas in MSY, MEY and OA conditions are static model bioeconomic that does not use discount rate in its optimization analysis. Clark in Pratiwi (2009) stated that the higher the discount rate, the lesser the economic gain/rents. This happens because the higher discount rate will stimulate an increase in resource hunting The impact is increasing pressure on these resources, which in turn will lead to resource degradation and extinction.

\section{Pelagic Fish Resources Management in Pati Regency}

Walden and McGuire (2011) stated that marine waters are common property resources, where fishermen have the same rights to utilize resources. The lack of control over their fishing efforts will have an impact on the sustainability of the fishing effort itself. Implementation of three provisions on fisheries management that can be done is as follows input control, output control, technical measures.

Input control can be done by limiting the total number of fishing effort. The total number of fishing effort can be reduced to the expected optimum extent to allow the stock of pelagic fish resources to be maintained.

Based on interview results, respondents stated that the number of boat with Purse
Seine fishing gear is too much. Arrangement of sailing permit for boat with Purse Seine fishing equipment due to the number of boat that have been too much can't be done immediately, because the business of fishing effort that is economically profitable makes it impossible to stop or transfer the pelagic fishing boat to other business activities. Purwanto in Purwanto (2011) stated that the control is the intensity of its capture by reducing the day or trip of catching, thus reaching or nearing the optimal capture intensity.

These input control can work well if there is any interference from the Government, as well as in the issuance of regulations regarding the limitation of the number of fishing efforts. Regulations are made based on a review of the sustainable potential level and the optimum level of return. Close supervision also needs to be done with strict punishment for the offender. It can also suppress the illegal fishing action of the fish capture businessman (Setiawan, 2016).

Based on the results of pelagic fish resource utilization analysis in Pati Regency on various conditions that are MSY, MEY, OA and OSY, it is recommended to use a reference based on the calculation results in OSY condition, considering the OSY analysis is dynamic and flexible to changes in the value of the resulting product (in the calculation using discount rate based on interest rate and inflation).

Management based on biological approach (MSY) in exploitation tends to be below the maximum point due to too much caution factor. While the management based on the economic approach (MEY) tend to be excessive due to the principle of profit. Merging the two approaches using a dynamic 
bioeconomic model that results in optimum exploitation conditions (OSY). Purwanto in Setiawan (2016) stated that the selection of dynamic models in resource management is due to a static approach only focusing on equilibrium conditions and ignoring changes in fish stock size from year to year, due to harvesting and the impact of the changes on the present value of future harvest.

The results of the analysis on OSY conditions obtained that the production of $25,218.883$ tons/year with the effort that is 151.266 units/year. If in 2016 based on data from Marine and Fisheries Agency of Pati Regency there are 287 units of purse seine and 849 gillnet, then alternative ideal number which can be taken into consideration based on result of standard effort analysis at OSY condition that are purse seine unit counted \pm 150 unit and gillnet unit counted \pm 900 unit.

Boat fishing and a number of inputs, fishermen can only control the production of their efforts, while the size of the catch can't be directly controlled. Thus, it can be said that economic benefits/rents will be obtained if the effort under control (Anderson, 1986).

Based on the interview result with respondents obtained a statement that the quality of Indonesian fishery products should be improved. One way to improve the quality of fishery products is by controlling the output. These Control means through limitation of catch size. This is so the captured pelagic fish resource is not an immature measure of gonad or that has not been reproduced. It is hoped that the restriction on the size of pelagic fish resources to be captured can capture the sires that already reproducing.
References from research results for the first size of mature gonads of several pelagic fishes were based on the results of Sujastani research in Krissunari and Hariati (1994) in the Java Sea, the first-size mature gonad for the Rastrellinger kanagurta was $19.0 \mathrm{~cm}$ with a range of 18.0-20.5 cm of total length with approximate at the fork length $17.1 \mathrm{~cm}$ with the range of 16.2-18.4 cm. For Selar crusmenophthalmus in Widodo and Suwarso's research in Krissunari and Hariati (1994), in Java waters with samples waters of the Java Sea from medium and large trawling fisheries in which female fish will mature gonad first at the fork length $18.0 \mathrm{~cm}$ while the male fish on the fork length $20.0 \mathrm{~cm}$. For Sardinella gibbosa, based on research of Atmadja et al in Krissunari and Hariati (1994), female fish caught in Java Sea waters mature gonad first time on the fork length $14.7 \mathrm{~cm}$.

Output control is strongly influenced by fishing business actors. Order in following the rule becomes the key to success in controlling this output. In general, output control is more difficult than input control. Supervision and checking of the accuracy of the catch data is obtained because business actors are easier in manipulating the existing data to increase the business profit (Setiawan, 2016).

Based on the interview result of respondents expect an effort to maintain the sustainability of the sea for the sustainability of fish resources. Thus, the technical measures of fishing can be done by the selectivity of environmentally friendly fishing gear and the setting of fishing season and fishing area.

Some examples of the application of fish resource management with the approach of fishing gear selectivity is the determination 
of minimum mesh size in purse seine and gillnet fishing gear. Based on the results of interviews with Head of Bajomulyo fish landing base, the rules about the specification of fishing gear are still common so it needs to be done more detail about the specification of fishing gear based on boat size.

Arrangement of capture season can be an alternative in fisheries management. Arrangement of capture season are intended to provide an opportunity for fish resources to breed (Putra, 2013). Beddington and Retting in Putra (2013) stated there were two closing forms of fishing season. First, close the fishing season at a certain time to allow fish to spawn and develop. Second, the closure of fishing activities because fish resources have been degraded.

Arrangement of capture season will result in closing of catch area at certain times. As a solution to the closure of fishing grounds, fishermen can be diverted to other fishing areas which, according to predictions, are not experiencing spawning season. Setiawan (2016) mentioned the supervision of the fishing area can also be helped by the Vessel Monitoring System, so that the fishery supervisor can find out whether the fishing area is suitable or not.

\section{CONCLUSION}

Maximum Sustainable Yield (MSY) condition : biomass 158.004 tons. The catch is $25,264.832$ tons. Effort 158.004 boat units. Profit IDR 546,512,048 or IDR 3.458.850 per boat unit. Maximum Economic Yield (MEY) condition : biomass 168.398 tons. The catch is $25,176.499$ tons. Effort 147.733 boat units. Profit IDR 1,026,645,483 or IDR 6,949,335 per boat unit. Open Access (OA) conditions : biomass 20.789 tons. The catch is $6,216.022$ tons. Efforts 295.466 boat units. Profit IDR o.

Optimum Sustainable Yield (OSY) conditions: biomass 167.498 tons. The catch is 25,173.617 tons. Effort 148.510 boat units. Profit IDR 1,101,262,976. The maximum gain obtained in optimal conditions is greater than in MSY, MEY and OA conditions.

The model of pelagic fish resources management are (a) input control, limiting the total number of fishing effort; (b) output control, limitation of catch size; (c) technical measures, selectivity of environmentallyfriendly fishing gear and arrange of fishing seasons and fishing grounds.

Based on the research findings, the suggestions are: (1) controlling the number of fishing effort and setting the number of production to the optimum level $\left(\mathrm{E}_{\mathrm{opt}}=\right.$ 148.510 units), under the condition of OSY, the number of purse seine units is \pm 148 units and the number of gillnet units is \pm 400 units. (2) Limit the size of fish that can be caught. (3) Monitoring, controlling, supervising, and enforcing the law with strict sanctions for scofflaw about the use of unsafe fishing gear. (4) Control of the seasons and catchment areas, especially closing the catchment area (closed season) during spawning ground. Fishing with alternate day and coastal conservation efforts. (5) Systematic monitoring, evaluation and data collection of fishery products shall be carried out consistently.

\section{REFERENCES}

Anderson, L. G. (1986) The Economic of Fisheries Management. USA: The John Hopkins University.

Bajomulyo fish landing base (2017) 'Data of Bajomulyo fish landing base Boat'. Pati.

Cahyani, R. T., Anggoro, S. and Yulianto, B. (2013) 'Sustainable Potential of Demersal Fish Resources (Analysis of Trawl captured Landing In Wedung Fish Auction Demak)', in Proceedings of the 
National Seminar on Resources and Environmental Management. Diponegoro University. Semarang., pp. 1-25.

Central Statistics Agency of Central Java Province (2015) Central Java In Figures Year 2014. Semarang. Available at: http://jateng.bps.go.id.

Central Statistics Agency of Central Java Province (2016) Central Java In Figures Year 2015. Semarang. Available at: http://jateng.bps.go.id.

Damayanti, H. O. (2014) 'Business Analysis and Development Strategy of Boiled Fish Industry in Pati Regency (Case Study: Boiled Fish Industry Operates All Year)'. Pati.

Damayanti, H. O., Susilowati, I. and Boesono, H. (2017) 'Analysis of Squid Net Fisheries Business Production', Journal of economics and Policy (JEJAK), 10(1), pp. 30-47. Available at: http://journal.unnes.ac.id/nju/index.php/jejak.

Directorate General of Capture Fisheries Ministry of Marine Affairs and Fisheries of Indonesia Republic (2015) 'Strategis Plan of 2015-2019'. Jakarta.

Ernaningsih, D. (2013) 'Bioeconomic Analysis of Small Pelagic Fish in Banten Bay', Jurnal Ilmiah Satya Negara Indonesia, (March Special Edition 2013), pp. 1-9.

Fauzi, A. (2010) Fisheries Economic. Jakarta : PT. Gramedia Pustaka Utama.

Fauzi, A. and Anna, S. (2005) Modeling of Fisheries and Marine Resources. Jakarta : PT. Gramedia Pustaka Utama.

Hasan, Iqbal (2005) Material Statistics 2 (Inferensive Statistics) Second Edition. Jakarta: Bumi Aksara.

Indonesian Bank (2017a) 'Basic Interest Rate of Credit'. Available http://www.bi.go.id/id/perbankan/suku-bungadasar/Default.aspx, accessed february 82017.

Indonesian Bank (2017b) 'Inflation Data'. Available at: http://www.bi.go.id/id/moneter/inflasi/data/Defau lt.aspx, accessed february 82017 .

Krissunari, D. and Hariati, T. (1994) 'First Sized Estimation of Mature Gonad of Several Small Pelagic Fish in North Waters of Rembang', Jurnal Penelitian Perikanan Laut, (No.85), pp. 48-53.

Marine Fisheries Research Center, Research Center for Fisheries Management and Conservation of Fish Resources, R. and D. A. for M. and F. (2014) 'Potential and Level of Utilization of Fish Resources in Fisheries Management Area of Indonesia Republic (FMAs Indonesia Republic)'. Jakarta : Ref Graphika.

Mulyani, S., Subiyanto and Bambang, A. N. (2004) 'Management of Anchovy Resources with Payang
Jabur Gear Through Bioeconomic Approach in Tegal Waters'. Semarang: Diponegoro University.

Nabunome, W. (2007) 'Model of Bioeconomic Analysis and Demersal Fish Resources Management (Empirical Study in Tegal City), Central Java'. Semarang: Diponegoro University.

Nikijuluw, V. P. H. (2002) Fishery Resources Management Regime. Jakarta : Regional Development and Empowerment Center.

Nurhayati, A. (2013) 'Analysis of Sustainable Potential of Capture Fisheries at Pangandaran Area', Jurnal Akuatika, IV(2), pp. 195-209.

Pratiwi, B. C. (2009) 'Bioeconomic Analysis as the Foundation for Rajungan Resources Management in Cirebon West Java Waters'. Thesis. Graduate program. Semarang : Diponegoro University.

Purwanto (2011) Multispecies-Multifleet Fishing Control in the Arafura Sea. Jakarta : Research Center for Fisheries Management and Conservation of Fish Resources.

Putra, S. E. (2013) 'Analysis of Sustainable Fishing Efforts in Climate Change Conditions'. Thesis. Master of Economics of Development Studies. Semarang : Diponegoro University.

Setiawan, H. A. (2016) 'Bioeconomic of Fishing Shrimp in the Arafura Sea. Exploitation of Coastal and Marine Resources Paper'. Master of Coastal Resources Management. Semarang : Diponegoro University.

Sparre, P. and Venema, S. (1999) Introduction of Tropical Fish Stock Assessment. Cooperation of FAO and Fisheries Research and Development Center. Jakarta: Agricultural Research and Development Agency.

Sutanto, H. A. (2015) Level of Production Efficiency and Small Business Income (Study of Salted Fish Processing in Pekalongan City). Semarang : Unnes Press.

Theresia, S. M., Pramonowibowo and Wijayanto, D. (2013) 'Bioeconomic Analysis of Squid Fishing (Loligo sp) in the coastal of Kendal Regency', Journal of Fisheries Resources Utilization Management and Technology, 2(3), pp. 100-110. Available at:

https://ejournal3.undip.ac.id/index.php/jfrumt/ar ticle/view/3814.

Walden, J. B. and McGuire, C. J. (2011) 'Who Owns The Fish? Moving From The Commons To The Federal Ownership Of Our National Fisheries', Marine Resources Committee Newsletter, 14(2), pp. 3-7.

Wijayanto, D. (2008) Fishery Bioeconomics Textbook. Faculty of Fisheries and Marine Science. Semarang. 